\title{
Erken Ergenlikte Ahlak Gelişimi: Bir Müdahale Araştırması
}

\author{
Berna Akçinar ${ }^{1}$, Nazlı Baydar ${ }^{2}$, Çiğdem Kağıtçıbaşı ${ }^{3}$ \\ ${ }^{1}$ Psikoloji Bölümü, Fen-Edebiyat Fakültesi, Işık Üniversitesi, Istanbul, Türkiye \\ ${ }^{2}$ Psikoloji Bölümü, Insani Bilimler ve Edebiyat Fakültesi, Koç Üniversitesi, Ístanbul, Türkiye \\ ${ }^{3}$ Psikoloji Bölümü, Insani Bilimler ve Edebiyat Fakültesi, Koç Üniversitesi, İstanbul, Türkiye
}

Sorumlu Yazar: Berna Akçinar, berna.akcinar@isikun.edu.tr

Makale Türü: Araştırma Makalesi

Araştırma/Proje Desteği: Koç Üniversitesi’nde “Erken Ergenlikte Pozitif Gelişme: Farklı Ortamlardaki Ergen Gelişimini Anlamak ve Desteklemek” isimli 111K392 no’lu TÜBİTAK 1001 projesi kapsamında yürütülmüştür.

Kaynak Gösterimi: Akçinar, B., Baydar, N., \& Kağıtçıbaşı, Ç. (2018). Erken ergenlikte ahlak gelişimi: Bir müdahale Araştırması. Eğitimde Kuram ve Uygulama, 14(2), 153-169. doi:10.17244/eku.322365

\section{Moral Development in Early Adolescence: An Intervention Study}

\author{
Berna Akçinar $^{1}$, Nazlı Baydar ${ }^{2}$, Çiğdem Kağıtçıbaşı ${ }^{3}$ \\ ${ }^{1}$ Department of Psychology, Faculty of Sciene and Literature, Işık University, İstanbul, Turkey \\ ${ }^{2}$ Department of Psychology, Faculty of Social Sciences and Humanities, Koç University, Istanbul, Turkey \\ ${ }^{3}$ Department of Psychology, Faculty of Social Sciences and Humanities, Koç University, Istanbul, Turkey
}

Corresponding Author: Berna Akçinar, berna.akcinar@isikun.edu.tr

Article Type: Research Article

Acknowledgement: This study was carried out in Koç University and supported by TÜBITAK with Project No: 111 K392 and title "Erken Ergenlikte Pozitif Gelişme: Farklı Ortamlardaki Ergen Gelişimini Anlamak ve Desteklemek”.

To Cite This Article: Akçinar, B., Baydar, N., \& Kağıtçıbaşı, Ç. (2018). Erken ergenlikte ahlak gelişimi: Bir müdahale araştırması. Eğitimde Kuram ve Uygulama, 14(2), 153-169. doi:10.17244/eku.322365 


\title{
Erken Ergenlikte Ahlak Gelişimi: Bir Müdahale Araştırması
}

\author{
Berna Akçinar ${ }^{1}$, Nazlı Baydar ${ }^{2}$, Çiğdem Kăğtçıbaşı ${ }^{3}$ \\ ${ }^{1}$ Psikoloji Bölümü, Fen-Edebiyat Fakültesi, Işık Üniversitesi, İstanbul, Türkiye \\ ORCID: http://orcid.org/0000-0003-4768-7463 \\ ${ }^{2}$ Psikoloji Bölümü, Insani Bilimler ve Edebiyat Fakültesi, Koç Üniversitesi, İstanbul, Türkiye \\ ORCID: http://orcid.org/0000-0001-6793-7402 \\ ${ }^{3}$ Psikoloji Bölümü, İnsani Bilimler ve Edebiyat Fakültesi, Koç Üniversitesi, İstanbul, Türkiye
}

\begin{abstract}
$\ddot{\mathbf{O ̈ z}}$
$\mathrm{Bu}$ çalışma, erken ergenlik dönemindeki ilköğretim öğrencilerinin ahlak gelişimlerine katkı sağlamayı hedefleyen bir müdahale programının değerlendirmesini içermektedir. Toplumun bir üyesi olma sürecinde, gerekli birçok değer, beceri ve davranış örüntüleri erken ergenlikte ortaya çıkar. 'Pozitif ergen gelişimi' kavramsal çerçevesi kapsamında da, bu dönemdeki ergenlerin gelişimlerini desteklemenin önemi vurgulanmaktadır. Çalışmanın verileri, uygulanmış bir müdahale programı olan 'Erken Ergenlikte Pozitif Gelişme: Farklı Ortamlardaki Ergen Gelişimini Anlamak ve Desteklemek' projesi aracılı̆̆ıyla toplanmıştır. Uygulanan eğitim programı ile pozitif ergen gelişimine katkısı olacağı düşünülen sosyal-duygusal ve ahlaki becerilerin öğrencilere kazandırılması amaçlanmıştır. Araştırmanın örneklemini, İstanbul'daki düşük ve orta sosyoekonomik düzeydeki 5'i kontrol 4'ü müdahale olmak üzere toplam 9 farklı ilköğretim okulundan, 925 öğrenci oluşturmaktadır. Çalışma kapsamında, ön-test, son-test ve takip verileri toplanmış ve program değerlendirme analizleri yapılmıştır. Çalışmanın sonuçları uygulanan eğitim programının, erken ergenlik döneminde tüm öğrenciler için olumlu etkileri olduğu gibi, ahlak gelişimi konusunda özellikle riskli konumda olan erkek öğrenciler için daha da yararlı olduğunu göstermektedir.
\end{abstract}

Makale Bilgisi

Anahtar Kelimeler: Ahlak gelişimi, Ergenlik, Müdahale, Pozitif ergen gelişimi

Makale Geçmişi:

Geliş: 29 Haziran 2017

Düzeltme: 15 Ocak 2018

Kabul: 04 Nisan 2018

Makale Türü: Araştırma Makalesi

\section{Moral Development in Early Adolescence: An Intervention Study}

\begin{abstract}
This study includes the evaluation of an intervention program which aims to contribute to the moral development of early adolescents. 'Positive youth development' framework stresses the importance of supporting the youth development in this particular age period. The data of the study was collected within a part of a broader intervention program called 'Positive Youth Development in Early Adolescence: Understanding and Supporting the Youth Development in Different Contexts'. Aim of the intervention was to support the positive development of adolescents in social-emotional and moral developmental areas. The sample was composed of 925 students from 9 elementary schools, 5 control and 4 intervention schools, with low and middle socioeconomic status background. The short term and long-term effects of the intervention were measured by posttest and follow-up tests, respectively. The results suggested that the intervention program was effective in supporting the moral development of all students during the early adolescence.
\end{abstract}

Keywords: Adolescence, Intervention, Moral development, Positive youth development

Article History:

Received: 29 June 2017

Revised: 15 January 2018

Accepted: 04 April 2018

Article Type: Research Article 


\section{Giriş}

Erken ergenlik, insan sosyalleşmesinde çok önemli bir gelişme dönemidir, çünkü birçok değer, beceri ve davranış örüntüleri erken ergenlikte ortaya çıkar. Ayrıca, bireyin hem bilişsel hem de sosyal-duygusal açıdan gelişme gösterdiği bir dönemdir (Schmid, Phelps, \& Lerner, 2011). Bu nedenle ergenlik, gelecek planlarının arttı̆̆ ve gençlerin kendilerini gelecekteki yetişkin hayatlarına doğru sevk edecek roller bulmaya, kişiliklerini ve öz tanımlarını geliştirmeye çalıştıkları bir dönem olarak tanımlanmıştır (Erikson, 1959; Schmid vd., 2011). Bu dönemdeki önemli bir gelişim alanı da ahlak gelişimidir. Ahlak, insanlar arasındaki ilişkiyi düzenleyen, kişilerin doğru ve yanlış davranışları ve tutumları arasındaki farkı bilip, doğru olanı değerlendirdikleri ilkeler ve yargılar sistemidir. Ahlak, bireyin kişilik gelişiminin önemli öğelerinden biri olup, kişilerarasındaki ilişkileri düzenlediğinden, toplumsal düzen ve huzur için de oldukça önemlidir ve sosyal çevrenin de etkisiyle öğrenilen bir gelişim özelliği olarak bilinmektedir (Kohlberg, 1971; Piaget, 1932).

Erken ergenliğin önemine rağmen, psikolojide ve gelişim araştırmalarında çok uzun bir süre öne çıkmadığını, özellikle bebeklik ve erken çocukluğa verilen dikkatin gölgesinde kaldığını görmekteyiz. Örneğin, bilişsel ve duygusal gelişim kuramlarında çocukluğa odaklanılmış olması, erken ergenlik araştırmalarının göreli olarak daha betimleyici ve kuram bakımından daha zayıf kalmasında rol oynamıştır. Türkiye'de de benzer bir durum söz konusudur. Bu nedenle, bu çalışmanın verilerinin dayandırıldığı müdahale programı olan Erken Ergenlikte Pozitif Gelişme (PERGEL) çalışmasının, bu eksikliği giderici, kuramsal ve uygulamalı katkı sağlayıcı önemli bir bilimsel girişim olduğu düşünülmektedir.

Ergenlik döneminin getirdiği sorumluluk ve beceri ihtiyaçlarına rağmen, birçok öğrenci bu sosyal ve duygusal becerilerden yoksun olabilmektedir (Blum \& Libbey, 2004). Bu nedenle ergenlik döneminde uygulanan sosyal, davranışsal ve bilişsel gelişimi destekleme veya risk önleme odaklı müdahale programlarının, ergen gelişimine katk1ları vurgulanmıştır (Campbell \& Ramey, 1995; Gillham vd., 2006; Pellegrini, Bartini, \& Brooks, 1999). Benzer şekilde, bu dönemde uygulanan sosyal ve duygusal müdahale programlarının (SEL) bireyin gelişiminde önemli bir rol oynamasının ve kabul edilmesinin nedeni de, yaşanılan bu zorluklardır. Bu programlar, ergenlere başkaları için empati geliştirmek, sorumluluk duygusu ile kararlar vermek, olumlu ilişkiler kurmak, doğru ve yanlış davranışları ayırt etmek ve zorlayıcı durumlarla etkin biçimde başa çıkabilmek gibi beceriler kazandırmayı amaçlar. Birçok çalışmanın bulguları, bu dönemde uygulanan programların, ergenlerin gelişimini olumlu yönde etkileyebileceğini açıkça ortaya koymaktadır (Roth \& Brooks-Gunn, 2003). Sosyal beceri kazandırmayı amaçlayan okullarda uygulanan müdahale programları, sağlıkı ilişkiler kurmak için duyguları yönetmek (Holsen, Smith, \& Frey, 2008), şiddet içeren ve saldırgan davranışları azaltmak (Elias 1997; Gottfredson vd., 2004; Payton vd., 2000) ve okul başarısına katkı sağlamak (Elias, 1997; Ragozzino, Resnik, Utne-O’Brien, \& Weissberg, 2003) gibi bir dizi farklı amaçlarla uygulanmıştır.

Okullarda uygulanan müdahale ya da önleme eğitim programlarının, birçok yönden avantajlı olduğu söylenebilir. Özellikle erken ergenlik ve ergenlik dönemlerinde, akranların ebeveynlerinden çok, birbirlerinden etkilendiği bilinmektedir (Gardner \& Steinberg, 2005). Bu nedenle, bu akran grubunun bir arada müdahale programına katılması çok etkili olabilmektedir. Aynı zamanda, okul ortamında sınıf kullanımı gibi olanaklar da bu tür eğitim programlarının daha kolay ve az maliyetle yürütülmesini sağlamaktadır. Böylece, bir arada bulunan çok sayıda öğrenciye, aynı anda ulaşabilme imkânıyla pozitif gelişime yönelik tutum ve davranış değişiklikleri sağlamak mümkün olabilmektedir.

$\mathrm{Bu}$ bağlamda, erken ergenlikte, bireylerin sosyal ve duygusal gelişimlerini desteklemeye yönelik eğitim programlarının daha çok uygulanmasına ve yaygınlaştırılmasına ihtiyaç olunduğu söyleyebiliriz. Bu çalışmanın amacı da, PERGEL araştırmasının bir parçası olarak, uygulanan eğitim programının erken ergenlerdeki ahlak gelişimine katkı yapıp yapmadığını araştırmaktır. Çalışmada, ergen gelişimini etkileyen cinsiyet gibi faktörler de eklenerek, kız ve erkek ergenlerin gelişimleri karşılaştırmalı olarak incelenmiştir. $\mathrm{Bu}$ amaçla da, bu evredeki gelişme süreçlerini pozitif ergen gelişimine doğru yönlendirici, ergenin esenliğini sağlayıcı ve yaygın kullanıma elverişli bir destek programı oluşturulmuştur.

\section{Çalışmanın Kuramsal Temeli}

PERGEL eğitimi programı, Kağıtçıbaşı'nın (1990; 2012) 'benlik kuramı' ve 'aile değişimi' kuramından ve pozitif ergen gelişimi kuramından (Lerner vd., 2005) yola çıkarak, bireyin ilişkilerini, benliğini ve kişiliğini geliştirmeye 
odaklanmıştır. Ahlaki olgunluk, doğru ve yanlış arasındaki farkı bilmek ve doğruyu seçmek ve doğru davranışları içselleştirmek demektir. Bu ahlaki olgunluk, Kağıtçıbaşı'nın kuramlarında vurguladığı gibi, sosyal çevrenin ve öğrenmenin etkisiyle oluşur. Bireyin içinde yaşadığı toplum, anne ve babasının eğitim durumu, bireyin eğitimi, ebeveynlerin olumlu ve ahlaklı tutumları ve yaşanılan sosyo-ekonomik çevrenin olumlu özellikleri, ahlak gelişimini etkileyen en önemli unsurlardır (Eisenberg \& Valiente, 2002; Nipkow \& Schweitzer, 1985; Walker \& Taylor, 1991). Pozitif ergen gelişimi kavramsal çerçevesi ve pozitif psikoloji yaklaşımı ise, erken ergenlikteki kişisel, sosyal ve duygusal gelişime odaklanılmıştır (Bornstein \& Cote, 2006; Lerner, Fisher, \& Weinberg, 2000; Roth \& Brooks-Gunn, 2003; Seligman, Reivich, Jaycox, \& Gilham, 1995). Pozitif ergen gelişimi, beş temel öğe ile ergen gelişimine değinmiştir: Yetkinlik (öz-yeterlilik), güven (öz-değer), bağlantılar, karakter (sorumluluk alma) ve şefkat (empati). Olumluluk, iyimserlik ve doğru-yanlışı ayırt edebilme ile de pekişen bu pozitif bakış açısı, genç ergenin genel olarak hem kendine, hem başkalarına karşı olumlu ve sorumluluk alan bir yetişkin olmaya doğru gelişiminin temelini oluşturur. (Narvaez, 2006; Seligman vd., 1995).

$\mathrm{Bu}$ çalışmanın ise, yukarıdaki kuramlar dışında, kavramsal çerçeve olarak özellikle yararlandığı diğer kuramlar da Piaget ve Kohlberg'in 'ahlak gelişimi' kuramlarıdır (Kohlberg, 1971; Piaget, 1932, aktaran Kağıtçıbaşı \& Cemalcılar, 2014, ss. 221-225). Piaget (1932), ahlak gelişimini bilişsel bir yaklaşımla inceleyerek, kural ve ilkelerin öğrenilmesi olarak tanımlamıştır. Piaget'e göre bu gelişim süreci, dışa bağlı ve özerk devre olarak tanımlanan iki farklı ahlaki devreden oluşmaktadır. Dışa bağlı devrede, ahlaki gerçekçilik önemlidir ve çocuk, yetki taşıyan kimselerce belirtilen kuralları kabul eder. Özerk devrede ise, kuralların durumsal gereksinimlere bağlı olarak değişebileceğini kabul eden birey, davranışların altında yatan nedenleri ve niyetleri değerlendirebilmekte ve göreli olabilecek kuralları içselleştirip kararlarında uygulayabilmektedir. Yani Piaget'e göre, özerk ahlak gelişim seviyesindeki birey, sadece kuralları öğrenmiş değil, aynı zamanda içselleştirmiş olmalıdır.

Kohlberg'e (1971) göre de ahlak, doğru ve yanlışı, iyiyi ve kötüyü değerlendirebilme ve bu bilişsel değerlendirme sonucunda davranışlarla sergileyebilme becerisidir. Kohlberg (1971) de geliştirdiği ahlak gelişimi kuramında, bireylerin evrensel ahlaki ilkeleri öğrenme konusunda, bazı ahlak gelişimi dönemlerinden geçtiğini belirtmiştir. Bu kurama göre, ahlak gelişimi, evrelerden oluşmaktadır ve birey bu evreleri sırayla geçmektedir. Kohlberg'in kuramına göre en alt seviye olan 'gelenek öncesi' düzeyde, birey bağımlılık ve ceza-itaat, bireycilik ve çıkara dayalı ilişki evrelerindedir. Bu düzeyde öncelikli olarak kendi gereksinimlerini düşünmekte olan birey, eğer ceza almayacağına inanırsa, ahlaki açıdan yanlış olan davranışları yapmaya çekinmeyecektir. Bir üst düzey olan kanun ve düzen, kişilerarası beklentiler ve uyum evrelerinden oluşan 'geleneksel' düzeyde, birey için toplumun tutumları ve beklentileri önemlidir. En üst seviye olan 'gelenek sonrası' düzeyde ise, sosyal anlaşma ve bireysel haklar ile evrensel ahlaki ilkeler önemlidir. Bu seviyede, bireysel hak ve özgürlüklerin önemli olduğu vurgulanmaktadır ve bu haklar toplumsal düzeni korumak ve yaşamı güvence altına almak içindir.

\section{Müdahale Programlarının Etkisi}

Okul çağındaki bireyler, aile ortamının yanı sıra, özellikle akranlarından ve öğretmenlerinin davranış ve tutumlarından da etkilenmektedirler. $\mathrm{Bu}$ nedenle, gelişimsel anlamda önemli yeri olan erken ergenlik döneminde de, okul ortamındaki davranış ve tutumların iyileştirilmeye çalışılmasına yönelik uygulanacak eğitim programlarının, ergenlerin ahlak gelişimlerine olumlu etkileri olacağı bilinmektedir (Senemoğlu, 1997). Yapılan bir meta analiz çalışmasının sonuçları, erken ergenlik dönemindeki ahlak gelişimi eğitim programlarının, öğrencilerin gelişimlerine olumlu etkileri olduğunu göstermiştir (Schlaefli, Rest, \& Thoma, 1985). Bu çalışmanın temelini oluşturan PERGEL projesine benzer olarak, Avustralya'da ergenlerle yapılan ve geniş uygulama imkânı bulan 'Aussi Programı'nda, programa katılanların uyumlu ve sosyal davranışlarında, ahlak gelişimlerinde ve iyimser düşünce becerilerinde ilerlemeler saptanmıştır (Quayle, Dziurawiec, Roberts, Kane, \& Ebsworthy, 2001; Roberts, 2006). Benzer şekilde, SEL programları kapsamında, kontrol gruplarına kıyasla, eğitim programına dahil olan öğrencilerin daha iyi sosyal ve duygusal beceriler ve empati geliştirdikleri ve ahlaki kuralları içselleştirmede daha başarılı oldukları bulunmuştur (Durlak, Weissberg, Dymnicki, Taylor, \& Schellinger, 2011).

Türkiye'de ise, ilköğretim öğrencilerine yönelik insani ve ahlaki değerler eğitimi programının sonuçları da, eğitim programının öğrencilerin ahlaki olgunluk düzeylerinde olumlu etkilerinin olduğunu bulmuştur (Dilmaç, 1999). Bir başka çalışma olan, 'yoğun düşünce eğitimi' programında da, Seçer (2003), erken ergenlik dönemindeki öğrencilerde, eğitimi alan öğrencilerin kontrol grubuna kıyasla, yanlış karar verme sayısının düşük olduğunu ve ahlaki 
yarg1 düzeylerinin önemli oranda daha yüksek olduğunu bulmuştur. Literatürdeki çalışmalarda, ahlak gelişiminde etkili olan bir etmenin de bireylerin cinsiyeti olduğu belirtilmiştir. Ancak, cinsiyetin ahlak gelişimiyle ilişkisini araştıran çalışmalar farklı bulgular edinmişlerdir. Bazı çalışmalar cinsiyetle ahlak gelişimi arasında bir ilişki bulmazken (Gölcük, 2010; Stephens, 2009), bazı çalışmalar da erkeklerin daha yüksek seviyede ahlak gelişimine sahip olduklarını göstermişlerdir (Haan, Langer, \& Kohlberg, 1976). Daha çok sayıdaki araştırma bulgusu ise, kadınların erkeklerden ve kız öğrencilerin erkek öğrencilerden daha yüksek seviyede ahlaki gelişim özellikleri gösterdiklerini bulmuştur (Bebeau, 2002; Gibbs, Basinger, Grime, \& Snarey, 2007; Mays, 2009; Silberman \& Snarey, 1993; Tolunay, 2001; White, 1999). Bu nedenle, bu çalışmada da öğrencilerin cinsiyetlerine göre ahlak gelişimleri ve yapılan eğitim programının etkileri ayrıca incelenmiştir.

Sonuç olarak, yapılan çalışmalar çocuk ve ergenlere yönelik bazı problemlerin tespitine ve müdahalesine farklı açılardan bakarak 1şık tutmuşlardır. Ergenlerin genel olarak, davranış problemleri, problem çözme becerileri, karar verme becerileri ve doğru-yanlış kavramları ayırt edebilme ile ilgili sorunlar yaşadıkları, yapılan çalışmalardan da sonuç olarak çıkartılabilmektedir. Ayrıca, çalışmalar, müdahale ve pozitif ergen gelişimi için her zaman umut olduğunu göstermektedir. Böylece, ergenlerde görülen bu problemler ile ilgili risk faktörleri azaltılırken, koruyucu faktörlerin de güçlendirilmesi ile ergenlerin sağlıkı davranışlarının ön plana çıkmasına yardımcı olacağı görüşü ileri sürülmektedir.

Bütün bu teorik ve ampirik bilgiler 1şığında, bu çalışmada, uygulanan eğitim programı olan PERGEL'in erken ergenlik dönemindeki öğrencilerin ahlak gelişimlerine olumlu etkisi olacağı beklenmektedir. Bu etki, kontrol ve deney okullarındaki öğrencilerin, değerlendirilen ahlak gelişimi ölçümlerinde fark elde edilmesiyle gösterilecektir. Ayrıca, eğitim programlarından daha düşük seviyede gelişim özellikleri gösteren alt örneklemdeki kişilerin, daha fazla yararlandığı bilinmektedir. Bu bağlamda, ahlak gelişimi daha düşük düzeyde olması beklenen erkek öğrencilerin, PERGEL eğitim programından daha fazla yararlanmaları beklenmektedir.

\section{Yöntem}

\section{Katılımcilar}

Araştırmadaki katılımcılar İstanbul'un farklı iki sosyoekonomik düzeyini (SED) temsil eden bölgelerinde yaşayan erken ergenlerdir. Proje, 6. sınıfın başındaki ortalama 11-12 yaşlarındaki öğrencilerle uygulanmaya başlamış ve bu öğrenciler 7. sınıfi tamamlayana kadar (12-13 yaş) projeye devam etmiştir. Tüm çalışmalar için İstanbul Milli Eğitim Müdürlüğ̈̈ ve okullarla işbirliği sağlanmıştır. Araştırmanın örneklemini İstanbul'daki 9 farklı ilköğretim devlet okulundan toplam 925 öğrenci oluşturmaktadır. Bu okulların 5'i kontrol grubu okulları 4'ü ise müdahale grubu okullarıdır.

Ön-test uygulamasında kontrol gurubu öğrenci sayıs1 417; müdahale grubu öğrenci sayıs1 508'dir. Bu okullardan 5'i orta, 4'ü düşük sosyoekonomik seviyedeki okullardır. Okulların sosyoekonomik düzeyleri, bağlı bulundukları mahalleye ve ilçeye göre belirlenmiştir. Okul örneklemi seçiminde, TÜiK tarafından belirlenmiş ve sosyoekonomik gelişmişlik düzeyi farklarına göre gruplandırmaya tabi tutulan, 'istatistiki bölge birimleri sınıflandırması' uygulanmıştır. Bu sınıflandırmaya göre belirlenen mahallelerin sosyoekonomik düzeyleri temel alınarak, çalışmaya dahil edilen okullar seçilmiştir.

Projeye katılacak her bir 6. sınıf şubesi için, benzer başka bir okuldan bir sınıf, kontrol grubu olarak değerlendirilmiştir. Kontrol grubu okullara herhangi bir eğitim verilmemiştir. Okullar birbirleriyle eşleştirilirken sosyo-ekonomik durum esas alınmış ve benzer sosyo-ekonomik özelliklerdeki okullar seçilmiştir. Projedeki aktiviteler Milli Eğitim Bakanlı̆̆ı'nca ders saati olarak belirlenmiş olan rehberlik saatlerinde gerçekleştirilmiştir. Program uygulandıktan sonraki son-test ölçümlerinde toplam örneklem sayıs1 789'dur (338 kontrol grubu, 451 müdahale grubu). Programın uzun vadedeki etkilerini ölçmek amacıyla yapılan takip araştırmasında örneklem sayısı ise 617'dir (239 kontrol grubu, 378 müdahale grubu). Programın uygulanmasında, toplam 4 okul ve 15 şubede, 11 lisans, yüksek lisans ve doktora öğrencisi uygulayıcı eğitimci olarak çalışmıştır. Şube sınıf mevcutları, okullara göre 24 ile 42 öğrenci arasında değişmektedir.

\section{İşlem}


Ölçeklerin, proje örnekleminin yaş grubu, SED, kültürel normlar gibi özelliklerine uygunluğu proje ekibi tarafindan incelenmiş ve hangilerinin pilot çalışmaya dahil edileceği kararlaştırılmıştır. Bu kararlardan sonra, pilot testler uygulanmış ve analizleri yapılmıştır. Pilot testlerin ve eğitim programının pilot uygulaması, İstanbul'daki 3 farklı ilköğretim devlet okulunda toplam 344 öğrenci ile gerçekleştirilmiştir. Yapılan pilot çalışmada ortaya çıkan sonuçlar neticesinde, hem ölçekler hem de eğitim programları son hallerine kavuşturulmuştur. Programın uygulanması için eğitici kitapçı̆̆ı ve eğitim sunumlarının yanı sıra, öğrencilerin aktif olarak katılabileceği ve örnek aktivitelerle öğrendiklerini pekiştirdikleri öğrenci kitapçıkları da hazırlanmıştır. İlköğretim okullarının ikinci kanaat döneminin başladığı ilk hafta (11 Şubat 2013), belirlenen günlerde proje eğitimcileri okullara gitmiş ve sınıflara sirayla girerek ön testleri uygulamışlardır.

Ön test uygulamalarından sonraki hafta olan 18 Şubat 2013 itibariyle sadece uygulama okullarına (deney grubu) her hafta rehberlik saatlerinde gidilerek bir ders saati boyunca on beş oturumluk ergen gelişimini destekleyecek müdahale programı uygulanmıştır. Toplamda 4 uygulama okuluna gidilmiş ve 11 sinıfta eğitimler sürdürülmüştür. Müdahale programı sırasıyla şu konu ve oturumları içermektedir: Değişebilirlik ve değişime inanma, duygular ve empatik düşünme, iletişim, otomatik düşünceler ve yorumlar, ilişkilere özen gösterme ve ilişkileri güçlendirme, farklı1ıklara saygı gösterme, olumsuz duygularla başa çıkma, uzlaşma, akran zorbalı̆̆ı, özerk-ilişkisel benlik ve karar verme, çaba ve başarı, ahlak gelişimi, gelecekte ben ve genel pekiştirme. Eğitimler, öğrencilerin aktif katılımını arttıracak şekilde daha çok tartışma, soru-cevap, oyun, hikaye anlatımı ve faaliyetler ile planlanmıştır.

Eğitimlerin son uygulama haftasında, son-test değerlendirmeleri uygulanmıştır. Son-test uygulamasından sonra, program kapsamında işlenen konuların, bir sonraki dönemlerde de öğrencilere hatırlatılması ve anlaşılmayan konuların tekrar edilmesi amaçlanmıştır. Bu nedenle, Mart 2014'te dört oturumluk pekiştirme eğitimi programı uygulanmıştır. Bu programın sonunda da tüm okullara gidilerek programın uzun vadeli sonuçlarını belirlemek için Mayıs 2014'te takip araştırması veri toplama işlemi gerçekleştirilmiştir.

$\mathrm{Bu}$ çalışma ise, uygulanan programın öğrencilerin ahlak gelişimleri hakkındaki etkilerini ölçmeyi amaçladığından, bu kısımda detaylı olarak sadece ahlak gelişimi oturumu hakkında bilgi verilmektedir. Ahlak gelişimi konusunda, öğrencilere kuralların neden var olduğu, doğru-yanlış kavramları ve doğru insan nasıl olunur kavramları hakkında bilgiler verilmiştir. Bu oturumda, öğrencilerin doğru ve yanlış kavramlarını tanımlama, doğru ve yanlış hareketler arasındaki farkları ayırt edebilme, değerlendirme yaparken hareketler kadar niyetleri de göz önünde bulundurma, kuralların konulma nedenini anlayabilme, doğru davranışları içselleştirip dışarıdan herhangi bir süpervizyon olmadığı durumlarda da sergileyebilme, bir karar vermeden önce doğru ve yanlış kavramlarını göz önünde bulundurma, doğruyu toplumsal olarak benimseme ve uygulayabilme ve adalet kavramının herkes için olduğunu anlayabilmeleri amaçlanmıştır.

\section{Veri Toplama Araçları}

$\mathrm{Bu}$ çalışmada, öğrencilerin raporladıkları ahlak gelişimi ölçümü ile kontrol değişkenleri olan öğrencini cinsiyeti, ailesinin sosyoekonomik düzeyi ve kümülatif aile risk indeksi ölçümleri kullanılmıştır.

\section{Demografik Bilgi Formu}

Demografik bilgiler, öğrencinin ailesi hakkında genel bilgileri ve kendi cinsiyetini içermektedir. Öğrencilerin kendi bildirdiği, anne ve babasının en son bitirdiği sınıf, onların eğitim düzeyini ölçmektedir. Ayrıca anne ve babanın işi hakkında da bilgi edinilmiştir. Ailenin ekonomik düzeyini ölçmek amacıyla farklı değişkenlerden oluşan toplam bir ekonomik düzey faktör puanı elde edilmiştir. Bu faktör puanına dahil olan değişkenler, annenin eğitimi, babanın eğitimi, ailenin oturmuş olduğu evin özellikleri (1sınma ve oda sayısı gibi) ve ailenin yaşadığı evde sahip olunan varlıklardır (bulaşık makinesi, araba, vb.). Analizlerde bu faktör puanı kullanılmıştır.

\section{Kümülatif Aile Risk İndeksi}

Ebeveyn davranışları kullanılarak kümülatif aile risk indeksi oluşturulmuştur. Öğrencilerin, kendi anne ve babalarının davranışlarını değerlendirdiği ölçek yoluyla elde edilen bu davranışlar, cezaya dayalı olumsuz anne ve babalık, anne ve babanın çocuğuna reddi ve düşük düzeyde anne ve baba sıcaklığıdır. Bu çalışmada Algılanan Ebeveynlik Tarzları Ölçeği (Sümer \& Güngor, 1999) kullanılmıştır. Algılanan Ebeveynlik Tarzları Ölçeği (Sümer \& Güngor, 1999) algılanan ebeveynlik sıcaklığını (örn., "Annen veya baban sana sevgisini sarılarak gösterir mi?), algılanan psikolojik 
reddedilmeyi (örn., “Annen seni arkadaşlarınla kıyaslar mı?”) ve algılanan psikolojik kontrolü (örn., “Annen veya baban sen konuşurken senin cümleni tamamlar mı?”) ölçmeyi sağlar. Her bir madde için çocuklardan, anne ve babalarını 5'li Likert tipi ölçek üzerinden değerlendirmeleri istenmiştir. Bu çalışmada, ebeveyn sıcaklığı, reddetme ve kontrol davranışları hem anne hem baba davranışları için ön-testte ölçülmüştür. Ölçeklerin iç tutarlık katsayıları anne ve baba için sırasıyla, kontrol davranışları için 0,72 ve 0,73 , ebeveyn sıcaklığı için 0,77 ve 0,80 , ebeveyn reddetme davranışları için ise 0,77 ve 0,74 olarak bulunmuştur.

\section{Ahlak Gelişimi Ölçeği}

Bu ölçek Buchanan-Barrow ve Barrett'ın (1998) araştırmasındaki senaryolardan yararlanılarak geliştirilmiştir. Seçer, Çağdaş ve Seçer (2006) bu araştırmadaki ölçeği Türkçe'ye çevirmiş ve uyarlamıştır. Ahlaki, sosyal, muğlak ve göreceli kurallar arasında fark olup olmadığını ölçmektedir. Bu ölçeğin farklı boyutları bulunmaktadır. Bu çalışmada ise, çalışmanın kuramsal temeline uygun olarak, özerk ahlak gelişim devresini yansıtan, kuralları içselleştirme boyutu kullanılmıştır. Araştırmamızda katılımcılara 5 durum sunulmuştur. Sunulan her beş durumu, kuralları içselleştirmek boyutunu temsil eden soru takip etmiştir.

Örnek bir varsayımsal durum şöyledir; "Kural dışı olmasına rağmen Melih Arda’yı iter ve Arda düşer”. Bu durumda, kuralları içselleştirme ile ahlak gelişimini ölçen soru şu şekildedir: "Melih'e kaydırakta oyalanarak diğerlerine engel olan birisini itebileceğini söylenseydi, Melih'in bunu yapması doğru olur muydu? Katılımcılardan sorulara "evet" ya da "hayır" olarak yanıt vermeleri istenmiştir. Ön-test, son-test ve takip araştırması için iç tutarlılık değerleri 0,72 ve 0,84 arasında değişmektedir.

\section{Bulgular}

Bu bölümde öncelikli olarak çalışma örnekleminin demografik özellikleri ve çalışma değişkenlerinin korelasyon analizi sonuçları özetlenmektedir. Daha sonra, yapısal eşitlik modeli ile, uygulanan eğitim programının ahlak gelişimine etkileri ve bu etkilerin kız ve erkek öğrenciler arasındaki farkları özetlenmektedir. Çalışmaya katılan kontrol ve deney grubundaki öğrencilerin demografik özellikleri Tablo 1'de verilmiştir. Ki-kare ve T-testi sonuçları göstermektedir ki PERGEL örnekleminde, kontrol ve deney grubu arasında demografik olarak herhangi bir fark yoktur. $\mathrm{Bu} \mathrm{da}$, eğitim programına başlarken iki grup arasında herhangi bir eşitsizliğin olmaması bakımından önemlidir.

Tablo 2, kontrol ve deney grupları için, bu çalışmadaki ahlak gelişimi ve kullanılan demografik bilgi değişkenlerinin ortalama ve standart sapma değerlerini ve kendi aralarındaki korelasyonlarını vermektedir. Sonuçlar göstermektedir ki, kümülatif aile risk indeksi ile öğrencilerin üç ayrı zamandaki ahlak gelişimleri arasında da istatistiksel olarak anlamlı ve negatif bir ilişki bulunmaktadır. Yani, olumsuz anne ve baba davranışlarını içeren ailenin risk düzeyi arttıkça, öğrencilerin ahlak gelişimleri azalmaktadır. Hem kontrol hem de deney grubundaki öğrencilerin, üç ayrı zamandaki ahlak gelişimleri, birbirleriyle olumlu olarak ilişkidedir. Ancak, ortalama değerler göstermektedir ki kontrol grubu öğrencilerinin ahlak gelişim düzeylerinde ciddi bir düşüş olurken, deney grubu öğrencileri, özellikle takip araştırması sonunda böyle bir düşüş göstermemektedirler.

\section{Ahlak Gelişimi için Müdahale Programının Etkisi}

Uygulanan PERGEL eğitiminin, öğrencilerin 'ahlak gelişimi' kavramı için müdahale programının etkisi, ön-test, sontest ve takip verilerinin analizleri ile, çok gruplu yapısal eşitlik modelleri kullanılarak MPLUS istatistiksel modelleme programı ile yapılmıştır. Model, üç araştırma noktasında (ön-test, son-test ve takip) kuralları içselleştirme boyutu olan ahlak gelişimi ile belirlenmiştir. Bu modelde, ahlak gelişimi faktörünün zaman içinde bir dinamiği olacağı, bundan dolayı da ön-test, son-test ve takip arasında otoregresyon ile ifade edilebilecek ilişkiler olduğu varsayılmıştır. Bütün bu dinamikleri bünyesinde barındıran model Şekil 1'de sunulmaktadır. Ahlak gelişimi faktörünün ön-test, son-test ve takip noktaları için hesaplanan sabit katsayıları (intercept) bu faktörün müdahale ve kontrol gruplarında zaman içinde nasıl değiştiğini göstermektedir. Model, müdahale ve kontrol grupları için ayrı ayrı tanımlanmış ve çok gruplu analiz yöntemi ile hesaplanmıştır.

Tablo 1. Çalışma örnekleminin demografik özellikler açısından karşılaştırılması 


\begin{tabular}{|c|c|c|c|c|}
\hline \multicolumn{5}{|c|}{ Çalışma Grubu } \\
\hline & $\begin{array}{c}\text { Kontrol } \\
\text { Grubu }\end{array}$ & $\begin{array}{l}\text { Deney } \\
\text { Grubu }\end{array}$ & $\chi^{2}$ & $d f$ \\
\hline \multicolumn{5}{|l|}{ Cinsiyet } \\
\hline K1z & $\begin{array}{c}195 \\
(\% 47)\end{array}$ & $\begin{array}{c}249 \\
(\% 49,1)\end{array}$ & 0,41 & 1 \\
\hline Erkek & $\begin{array}{c}220 \\
(\% 53)\end{array}$ & $\begin{array}{c}258 \\
(\% 50,9)\end{array}$ & & \\
\hline \multicolumn{5}{|l|}{ Annenin eğitim durumu } \\
\hline Annesi liseye gitmemiş olanlar & $\begin{array}{c}160 \\
(\% 49,8)\end{array}$ & $\begin{array}{c}198 \\
(\% 50,4)\end{array}$ & 0,02 & 1 \\
\hline Annesi liseye gitmiş olanlar & $\begin{array}{c}161 \\
(\% 50,2)\end{array}$ & $\begin{array}{c}195 \\
(\% 49,6)\end{array}$ & & \\
\hline \multicolumn{5}{|l|}{ Babanın eğitim durumu } \\
\hline Babası liseye gitmemiş olanlar & $\begin{array}{c}183 \\
(\% 58,9)\end{array}$ & $\begin{array}{c}252 \\
(\% 63,5)\end{array}$ & 2,29 & 1 \\
\hline \multirow[t]{3}{*}{ Babası liseye gitmiş olanlar } & $\begin{array}{c}133 \\
(\% 42,1)\end{array}$ & $\begin{array}{c}145 \\
(\% 36,5)\end{array}$ & & \\
\hline & \multicolumn{2}{|c|}{ Çalışma Grubu } & & \\
\hline & $\begin{array}{c}\text { Kontrol } \\
\text { Grubu }\end{array}$ & $\begin{array}{l}\text { Deney } \\
\text { Grubu }\end{array}$ & $t$ & $d f$ \\
\hline Evde sahip olunan varlıklar $(0-11)$ & $\begin{array}{c}8,34 \\
(2,68)\end{array}$ & $\begin{array}{c}8,33 \\
(2,80)\end{array}$ & 0,024 & 693 \\
\hline Kümülatif aile risk indeksi (0-6) & $\begin{array}{c}1,32 \\
(1,55)\end{array}$ & $\begin{array}{c}1,50 \\
(1,65)\end{array}$ & $-1,703$ & 871 \\
\hline $\mathrm{N}$ & 415 & 507 & & \\
\hline
\end{tabular}

Tablo 2. Çalışma değişkenlerinin ortalama ve standart sapma değerleri ile korelasyonları

\begin{tabular}{|c|c|c|c|c|c|c|}
\hline & $\begin{array}{c}\text { Kontrol Grup } \\
\text { Ortalama } \\
(\mathrm{SS}) \\
\end{array}$ & $\begin{array}{c}\text { Deney Grup } \\
\text { Ortalama } \\
(\mathrm{SS}) \\
\end{array}$ & 2 & 3 & 4 & 5 \\
\hline 1. Ailenin sosyo- & 0,06 & $-0,05$ & $-0,10$ & 0,01 & $0,11 *$ & 0,02 \\
\hline ekonomik düzeyi & $(0,93)$ & $(1.05)$ & $-0,14^{*}$ & 0,09 & $0,11 *$ & 0,03 \\
\hline 2. Kümülatif aile risk & 1,32 & 1,50 & & $-0,24 * *$ & $-0,10$ & $-0,26 * *$ \\
\hline indeksi & $(1,54)$ & $(1,65)$ & & $-0,17 * *$ & $-0,22 * *$ & $-0,17 * *$ \\
\hline 3. İçselleştirilmiş ahlak & 79,14 & 75,46 & & & $0,21 * *$ & $0,36 * *$ \\
\hline gelişimi & $(27,63)$ & $(29,27)$ & & & $0,34 * *$ & $0,32 * *$ \\
\hline \multicolumn{7}{|l|}{ ön-test } \\
\hline 4. İçselleştirilmiş ahlak & 64,43 & 68,06 & & & & $0,40 * *$ \\
\hline gelişimi & $(36,51)$ & $(33,91)$ & & & & $0,36 * *$ \\
\hline \multicolumn{7}{|l|}{ son-test } \\
\hline 5. İçselleştirilmiş ahlak & 65,86 & 75,01 & & & & \\
\hline gelişimi & $(34,36)$ & $(32,23)$ & & & & \\
\hline Takip & & & & & & \\
\hline
\end{tabular}

Notlar:

$1 . * p<.05 ; * * p<.01$.

2. İçselleştirilmiş ahlak gelişimi değerleri 0-100 arasında değişmektedir. Kümülatif aile risk indeksi ise 0-6 arasında değişmektedir.

3. Korelasyon değerlerinde, düz yazılmış olanlar kontrol grubu için, italik ile yazılmış değerler deney grubu içindir.

Ahlak gelişimi faktör dinamiğinin deney ve kontrol grupları için hesaplanmasını sağlayan model, temel dinamik modelimizdir. Daha sonraki adımlarda bu temel modele kontrol değişkenleri eklenmiştir. Sırasıyla öğrencinin cinsiyeti, sosyoekonomik düzey (anne ve baba eğitimi, evde sahip olunan varlıklar) ve kümülatif aile risk indeksi (cezaya dayalı olumsuz anne ve babalık, anne ve babanın çocuğunu reddi, düşük düzeyde anne ve baba sıcaklığı) modele eklenerek, son model elde edilmiştir. Modelin uyum iyilik indeksi iyidir: $\chi^{2}(12)=49,597, p=0,00$; CFI $=0,85$; RMSEA $=0,08$ ve SRMR=0,06. Yani elde edilen model, datanın iyi bir temsilidir. 


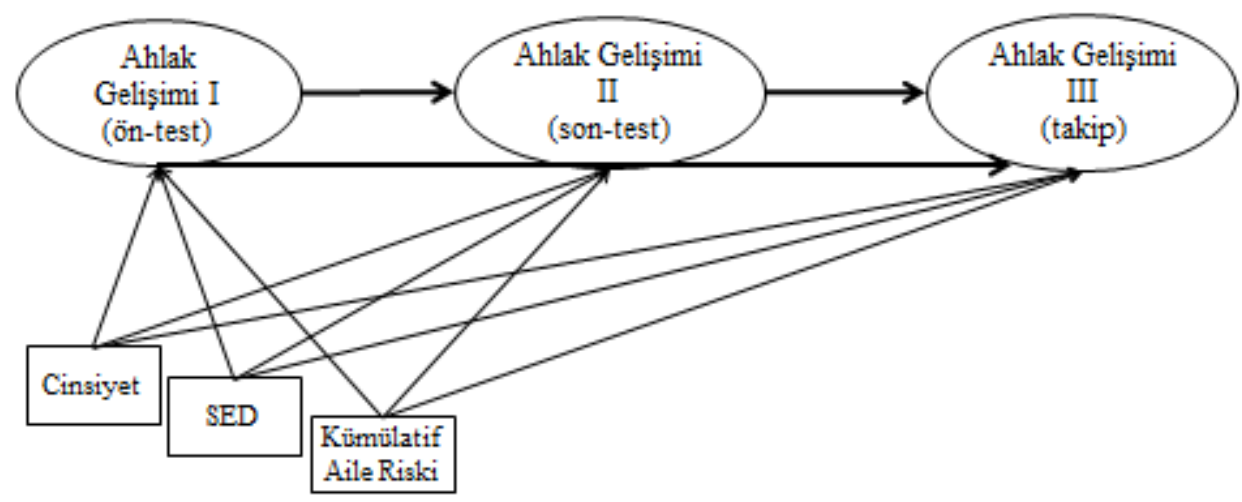

Şekil 1. Çok Gruplu Yapısal Eşitlik Analiz Modeli - Ahlak Gelişimi

Ahlak gelişimi faktör dinamiğinin deney ve kontrol grupları için hesaplanmasını sağlayan model, temel dinamik modelimizdir. Daha sonraki adımlarda bu temel modele kontrol değişkenleri eklenmiştir. Sırasıyla öğrencinin cinsiyeti, sosyoekonomik düzey (anne ve baba eğitimi, evde sahip olunan varlıklar) ve kümülatif aile risk indeksi (cezaya dayalı olumsuz anne ve babalık, anne ve babanın çocuğunu reddi, düşük düzeyde anne ve baba sıcaklığı) modele eklenerek, son model elde edilmiştir. Modelin uyum iyilik indeksi iyidir: $\chi^{2}(12)=49,597, p=0,00$; $\mathrm{CFI}=0,85$; RMSEA $=0,08$ ve $S R M R=0,06$. Yani elde edilen model, datanın iyi bir temsilidir.

Ahlak gelişimi için müdahale programının etkisi Şekil 2'de gösterilmektedir. Bu etki, öğrencinin cinsiyeti, SED ve kümülatif aile risk indeksi kontrol edildikten sonra elde edilmiştir. Ön-test ölçümlerinin sonuçlarına göre, kontrol okullarındaki öğrenciler deney okullarındaki öğrencilere göre biraz daha yüksek seviyede ahlak gelişimi göstermelerine rağmen, takip araştırması sonucunda, kontrol okullarındaki öğrenciler, deney okullarındaki öğrencilere kıyasla ahlak gelişimi konusunda daha geride kalmışlardır. Takip araştırması sonunda, deney okullarındaki öğrencilerde, beklenen yönde bir artış olmuş ve programın sonunda daha üstün bir gelişim göstermişlerdir. Kontrol okullarındaki öğrencilerin, özellikle ön-test ve son-test ölçümleri sırasında içselleştirilmiş ahlak gelişimlerinde düşüş gözlenmiştir. Buna kıyasla, deney okullarındaki öğrenciler, az bir artış eğilimi ile sabit bir ahlak gelişimi göstermiştir. $\mathrm{Bu}$ sonuç göstermektedir ki, erken ergenlik gibi riskli bir dönemde, PERGEL eğitim programı öğrencilerin ahlak gelişimine olumlu katkıda bulunmuştur. Böyle bir dönemde, olumlu gelişim özelliklerinin düşüş göstermeden, sabit kalması bile oldukça önemlidir.

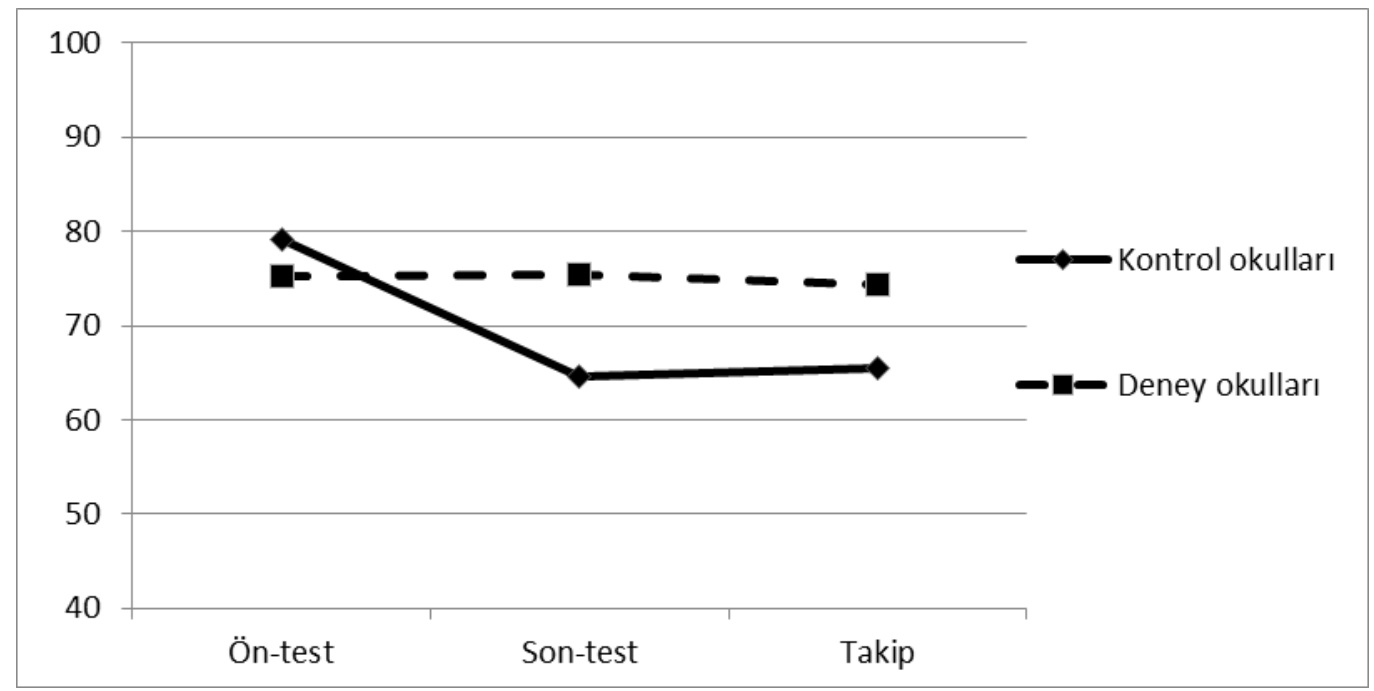

Şekil 2. PERGEL müdahale programının Ahlak Gelişimi üzerine etkisi

\section{PERGEL eğitiminin ahlak gelişimi kapsamında öğrencilerin cinsiyetlerine göre etkisi}

Ahlak gelişiminin kız ve erkek öğrencilerde farklılık göstereceği beklenmektedir. Bu nedenle, PERGEL eğitiminin ahlak gelişimi konusundaki kontrol ve deney grupları karşılaştırmasına ek olarak, bu gruplardaki kız ve erkek 
öğrencilerde nasıl farklılaştı̆̆ını da görebilmek için yine MPLUS programında, kız-erkek ve deney-kontrol okulları olmak üzere, çok gruplu yapısal eşitlik modeli kullanılarak analizler yapılmıştır. Elde edilen modelin uyum iyilik indeksi oldukça iyidir: $\chi^{2}(18)=24,943, \mathrm{p}=0,12 ; \mathrm{CFI}=0,95$; $\mathrm{RMSEA}=0,05$ ve $\mathrm{SRMR}=0,05$. Bu analizlerin sonuçları aşağıdaki, Şekil 3 ve Şekil 4'te verilmektedir.

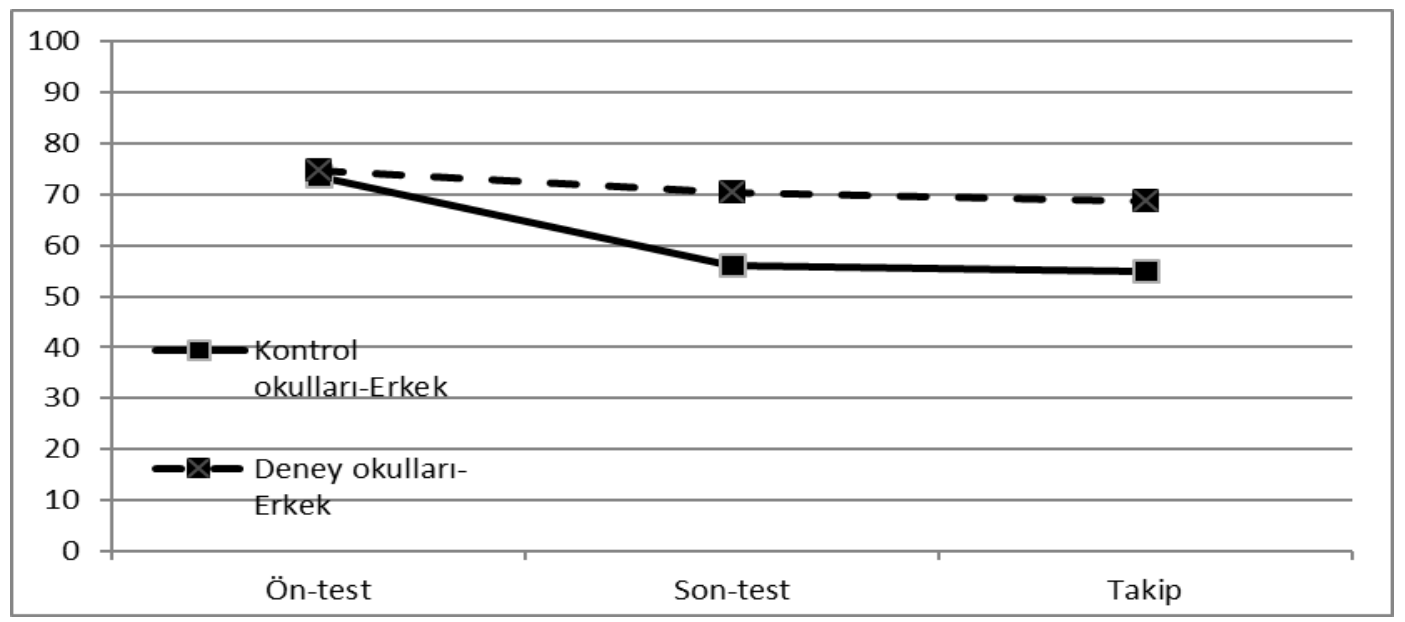

Şekil 3. Erkek öğrenciler için PERGEL müdahale programının Ahlak Gelişimi üzerine etkisi

Kontrol ve deney gruplarındaki erkek öğrencilerin ahlak gelişimi düzeyleri ön-test ölçümlerinde eşit olmalarına rağmen, kontrol okullarındaki erkek öğrenciler için bu kavramda düşüş gözlemlenirken, deney okullarındaki erkek öğrencilerin ahlaki kuralları içselleştirme becerilerinde büyük ölçüde sabitlik gözlemlenmektedir. Kız öğrenciler için ise, her iki grupta da erkek öğrencilere kıyasla yüksek seviyede ahlak gelişimi gösteren bir eğilim görülmektedir. Kontrol okullarındaki kız öğrencilerde, eğitim programı süresince (ön-test ve son-test ölçümleri arasında) bir düşüş görülürken, deney okullarındaki kız öğrenciler, sabit ve yüksek bir gelişim düzeyi göstermektedirler. Erkek ve kız öğrencilerin, pekiştirme eğitimi dahil, yani takip analizleri sonucunda, müdahale programından yararlanma etkilerine bakıldığında ise, erkek öğrencilerin ahlak gelişimi konusunda eğitim programından kız öğrencilere kıyasla daha fazla yararlandıkları bulunmuştur (etki büyüklüğü kızlar için \%2 iken erkekler için \%4'tür). Kız öğrenciler, zamanla normal gelişim özelliği olarak ahlak gelişimi kavramlarını öğrenebilseler de, bu durum erkek öğrenciler için kolay olmamaktadır. Bu sonuçlar da, PERGEL eğitiminin ahlak gelişimi ve ahlaki kuralları içselleştirme konusunda, başarılı olduğunu ve özellikle bu kavramda daha düşük gelişim düzeyi göstermesi beklenen erkek öğrencilerin, programdan daha fazla yararlandığını göstermektedir.

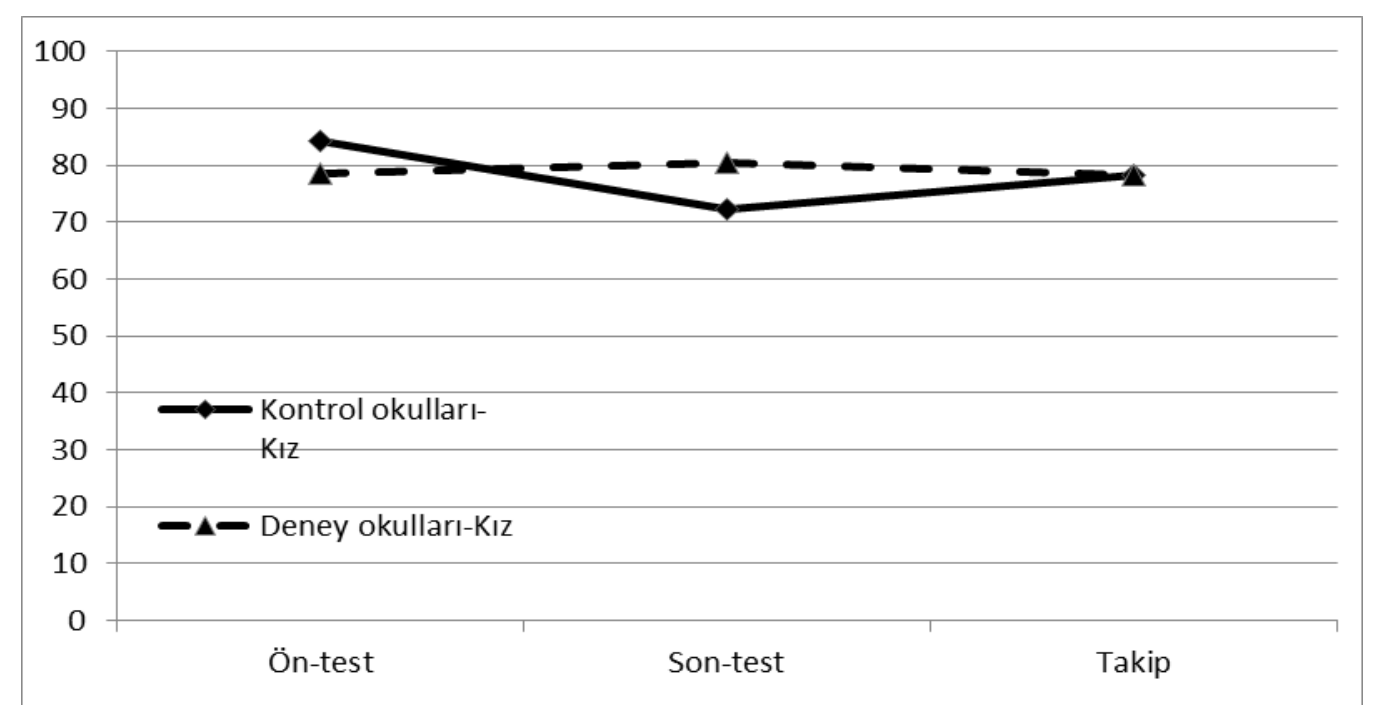

Şekil 4. Kız öğrenciler için PERGEL müdahale programının Ahlak Gelişimi üzerine etkisi 
İnsan kapasitesinin ve esenliğinin arttırılması, toplumsal gelişme gündeminin birinci maddesi olmak durumundadır. İnsana yatırım ise erken yaşlardan itibaren başlamalıdır. Yapılan daha önceki çalışmalarda, erken çocukluk döneminin, sosyal, duygusal ve davranışsal gelişim açısından duyarlı bir dönem olduğu görülmüştür (Kağıtçıbaş1, 2002; Kağıtçıbaşı, Sunar, \& Bekman, 2001; Kağıtçıbaşı, Sunar, Bekman, Baydar, \& Cemalcılar, 2009). Okul öncesi yaşlara odaklanan bu çalışmaların Türkiye çapında - ve yurt dışındaki - geniş uygulamalarının çok yarar sağladığı bulunmuştur. Erken ergenlik döneminin ise yine sosyal, duygusal ve davranışsal gelişim açısından ikinci duyarlı dönem olduğu bilinmektedir. Bu nedenle, erken ergenlik, müdahale için uygun bir gelişim dönemi olmaktadır. Erken ergenlikte pozitif gelişimin desteklenmesi, sorumluluk sahibi ve ahlaklı bireylerin ve daha iyi vatandaşların yetiştirilmesine temel teşkil etmektedir. Bu nedenle, ergenlerin esenliğini arttıran ve potansiyellerini en üst düzeye çıkaran eğitim ortamlarını tasarlamak oldukça önemlidir.

Uygulanmış PERGEL projesi ve bu çalışmada konu olan ahlak gelişimi kavramı, öğrencilerde, pozitif ergen gelişiminin farklı yönlerini oluşturan olumlu ve sağlıklı özellikleri güçlendirmeyi amaçlamıştır. Öğrencilerin doğru ve yanlış kavramları hakkında konuşmaları ve değerlendirme yapmaları ile doğru davranışları toplumsal olarak benimseme ve uygulama konusunda herkese eşit ve adaletli olunması gerektiği konularında eğitim almaları, riskli bir dönem olan erken ergenlikte, onların ahlak gelişim düzeylerini koruduğu, hatta olumlu yönde arttırdığı bulunmuştur. Uygulanan programın, erken ergenlerin özerk ve içselleştirilmiş ahlak gelişimlerine katkısı olduğu bulgusu, çalışmanın dayandırılmış olduğu kavramsal çerçeve ile de örtüşmektedir. Bu sonuç da PERGEL müdahale programının uzun vadede, okullarda uygulanan bir eğitim programı olması halinde, toplumsal iyilik için de önemli bir adım olacağını göstermektedir. Bu dönemde pozitif yönde gelişmeyi başaran erken ergen, ileride geç ergenlik ve yetişkinlikte sorunlarla daha iyi başa çıkan, ahlaklı ve adil daha 'iyi' bir vatandaş olmaya adaydır.

Genç ergenlere odaklanan, geniş çaplı ve geçerli bulgulara dayanan ve bilimsel temelli müdahale/önleme ve destek programlarına ihtiyaç olduğu, bu çalışmanın en önemli önerilerinden biridir. Türkiye'de ilköğretim orta okullarındaki rehberlik dersleri müfredatının, bu çalışmada önerilen türde bilimsel kuram ve temellere dayalı, etkin olduğu bilinen eğitim yöntemlerini içeren ve etkinliği deneysel desen ile ampirik olarak kanıtlanmış programlar içermediği görülmektedir. Ayrıca müfredatın, yaşa uygun sosyal-duygusal ve davranışsal becerilerin gelişmesine odaklanan öğrenme ve faaliyetleri yeterince içermediği veya uygulamada eksik kaldığı gözlenmiştir. Bu eksikliği giderebilmek adına, ergen gelişimine katkısı olduğu bilinen, öğrenmenin ve gelişimin mümkün olduğunu kavramsal çerçeve ve bulunan sonuçlarla gösteren bu çalışma oldukça önemlidir. PERGEL projesinde sunulan eğitim programının, ilköğretim ortaokul rehberlik saatlerinde uygulanması uzun vadeli bir öneridir. Özellikle, müdahale programlarının geniş kitlelere ulaşması ve daha az maliyetle uygulanmasının, bu şekilde sağlanması amaçlanmaktadır.

Erken ergenlerle uluslararası ve ulusal alanlarda yapılan müdahale çalışmaları da, bu yaş grubundaki eğitimlerin faydalarını vurgulamışlardır. Özellikle okul ortamında uygulanan programların geniş çaplı kitlelere ulaşabilmesi açısından etkili olduğu bilinmektedir. Bu çalışmadaki uygulamaya benzer olarak, Avustralya'da ergenlerle yapılan ve okullarda uygulanan 'Aussi Programı' sonuçları da, programa katılan ergenlerin sosyaldavranışsal ve ahlak gelişimlerinde olumlu gelişmeler gösterdiklerini bulmuştur (Quayle, Dziurawiec, Roberts, Kane, \& Ebsworthy, 2001; Roberts, 2006). Aussi Programı', benzer içerikte oluşturulan ve ABD'de Latin kökenli ergenlerle (Cardemil vd., 2002) ve Çinli ergenlerle (Yu \& Seligman, 2002) yapılan uygulamaları da olumlu sonuçlar veren "Penn Optimism Programı"ndan (Gillham, Reivich, Jaycox, \& Seligman, 1995) yararlanmıştır. Yani, PERGEL çalışmasına benzer olan uygulanmış programların, farklı sosyo-kültürel yapıya sahip öğrenciler için de olumlu sonuçları olduğu çeşitli çalışmalarla kanıtlanmıştır. Türkiye'de de yapılan bazı çalışmalar, ilköğretim öğrencileriyle uygulanan eğitim programlarının başarılı sonuçları olduğunu göstermiş̧tir. Dilmaç (1999), ilköğretim öğrencilerine yönelik insani ve ahlaki değerler eğitimi programı ile öğrencilerin doğru davranış, dürüstlük ve ahlaki olgunluk düzeylerinde artış gösterdiklerini bulurken, Seçer (2003) de, uyguladığı programla erken ergenlik dönemindeki öğrencilerin doğru kararlar verme ve ahlaki yargı düzeylerinde artış gösterdiklerini bulmuştur.

Bazı riskli grupların, eğitim ve müdahale programlarından, daha fazla faydalandığı bilinmektedir (Barrera vd., 2002; Reid, Webster-Stratton, \& Baydar, 2004). Literatürde de ahlak gelişimi açısından, erkeklerin kadınlardan daha dezavantajlı oldukları bulguları bulunmaktadır (Bebeau, 2002; Tolunay, 2001; White, 1999). Bu çalışmada da görülmüştür ki ergenlerin ahlak gelişimlerinde çeşitli farklılıklar vardır. Ahlak gelişimi eğitim programından, erkek öğrencilerin daha etkin bir biçimde faydalandığ bulunmuştur. Bunun nedeni de, ahlak gelişimi açısından erkek 
öğrencilerin daha düşük seviyede gelişim özelliği göstermeleri ve daha riskli konumda olmalarıdır (Mays, 2009; Silberman \& Snarey, 1993).

Gelişim psikolojisi araştırmaları ve sosyal psikoloji araştırmalarının bakış açılarını benimseyerek bir çalışmada toplamış olan PERGEL projesi ve kapsadığı bu çalışma, hem ergenlerin değişen çevrelerdeki gelişimsel sorunları ile ilgili önemli bilgiler ortaya koymuş, hem de erken ergenlik dönemindeki öğrencilerin ahlak gelişimlerini olumlu düzeyde etkileyerek toplumsal sorunlar üzerinde odaklanmıştır. Bu çalışma, erken ergenlik dönemindeki öğrencilere doğru-yanlış kavramlarını ayırt edebilme, doğru davranışları içselleştirme ve doğru davranışları toplumsal olarak uygulayabilme konusunda adil olma becerisi kazandırarak, onların ahlak gelişimlerine önemli katkıda bulunmuştur. Böylece, hem bireysel, hem ikili ilişkilerde, hem de toplumsal ilişkiler bazında erken ergenlere olumlu gelişimsel katkılar sağlanmıştır. 


\section{Extended Summary}

\section{Introduction}

The moral development is a part of the cognitive, social-emotional, and behavioral development which is crucial for the personality development of the individuals during the early adolescence period (Erikson, 1959; Kohlberg, 1971; Piaget, 1932; Schmid, Phelps, \& Lerner, 2011). The intervention programs aim to improve the positive youth development during this period become important, because many adolescence may lack the necessary social and behavioral skills (Campbell \& Ramey, 1995; Gillham et al., 2006; Pellegrini, Bartini, \& Brooks, 1999; Roth \& Brooks-Gunn, 2003). The results of the intervention programs applied at schools indicated that, these programs were beneficial to improve the emotion regulation and communication skills (Holsen, Smith, \& Frey, 2008), to decrease the aggressive behaviors (Elias 1997; Gottfredson et al., 2004; Payton et al,. 2000), and to increase the school success (Elias, 1997; Ragozzino, Resnik, Utne-O’Brien, \& Weissberg, 2003).

The general theoretical frame used for this study was the "Positive Youth Development" (Lerner et al., 2005) in which the significant concepts of the positive youth development approach are self-esteem and self-respect; positive outlook and optimism; attribution, empathy, and social-competence; implicit character and intelligence beliefs; intergroup behaviors and conflict resolution skills (Bornstein \& Cote, 2006; Lerner, Fisher, \& Weinberg, 2000; Narvaez, 2006; Roth \& Brooks-Gunn, 2003; Seligman, Reivich, Jaycox, \& Gilham, 1995). In addition, this study also adopted "Family Change Theory" of Kağıtçıbaşı $(1990 ; 2012)$ suggesting that the culture, the socio-economic status of the family, the parenting behaviors are known as the most important factors affecting the moral development of the individuals (Eisenberg \& Valiente, 2002; Nipkow \& Schweitzer, 1985; Walker \& Taylor, 1991), and Piaget and Kohlberg's moral development theories (Kohlberg, 1971; Piaget, 1932).

Many study results indicated that moral development intervention programs were efficient for the early adolescences to improve their moral, social and behavioral development (Schlaefli, Rest, \& Thoma, 1985; Senemoğlu, 1997). A similar intervention program as the current study that was applied in Australia, the Aussi Program, was also found to be effective in increasing the adaptive and social behaviors in early adolescences (Quayle, Dziurawiec, Roberts, Kane, \& Ebsworthy, 2001; Roberts, 2006). The students of the intervention group, as compared to the control groups, were found to be better in social and emotional skills, to develop more emphatic behaviors, and to be better internalize the moral rules (Durlak, Weissberg, Dymnicki, Taylor, \& Schellinger, 2011). Studies conducted in Turkey also showed that, students who attended the educational programs about humanity and moral values showed better thinking and decision making abilities, and had higher levels of moral judgment (Dilmaç, 1999; Seçer, 2003). However, there are inconsistencies about the effects of gender on moral development. Some studies indicated that women had better moral development than men (Bebeau, 2002; Gibbs, Basinger, Grime, \& Snarey, 2007; Mays, 2009; Silberman \& Snarey, 1993; Tolunay, 2001; White, 1999), while others found no association (Gölcük, 2010; Stephens, 2009) or found that men scored better in internalized moral judgements than women (Haan, Langer, \& Kohlberg, 1976).

\section{Purpose}

The primary aim of the study (PERGEL) was to better understand the early adolescence development in sociocultural and economic terms. The relations between the adolescent and the family, and the values and behaviors of adolescents were examined. The second aim of the study was to support the positive development of adolescents in moral developmental area. The intervention program was implemented in an experimental design, and short term and long term effects of the intervention were measured by the posttest and follow-up tests, respectively.

\section{Method}

\section{Method}

In this study, early adolescents at 6th grade, from different backgrounds, have been examined and one year impacts of the program have been determined with pre-posttest and follow-up studies. The studies were conducted at primary schools in middle socio- economic and lower socio-economic level environments in Istanbul, in which 5 schools were included as the control groups and 4 as the intervention group ( $\mathrm{N}=925)$. 


\section{Procedure}

An education session based on the moral development only for the intervention group was given. The students learnt about the identification and differentiation of right and wrong behaviors, the reasoning about the rules, the internalization of the right behaviors even in the absence of an authority, and the application of the right behaviors.

\section{Measures}

All data were gathered by the students' self-reports. Demographic information about gender, economic status, educational level of mothers and fathers, occupational status of mothers and fathers was collected. A factor score was calculated on the basis of maternal education, paternal education, and a composite measure of family economic wellbeing that combined information on the material possessions of the family (e.g., a car, a dishwasher, a computer), and monthly per person expenditures of the household.

Cumulative family risk index was calculated by measuring the parenting behaviors. Both maternal and paternal behaviors of negative and rejecting, and positive and warmth behaviors were included. The Perceived Parenting Styles Scale (Sümer \& Güngor, 1999) measured the parenting warmth, psychological control, and psychological rejection with 5 point Likert scale. The internal reliability for controlling parenting was 0.72 and 0.73 , for parental warmth was 0.77 and 0.80 , and for rejecting parenting was 0.77 and 0.74 for the mothers and fathers, respectively.

This scale was developed from Buchanan-Barrow and Barrett's (1998) scenarios and was adapted to Turkish by Seçer, Çağdaş, and Seçer (2006). It measures various dimensions of moral development, but in the current study only the internalizing the rules subscale was used. This subscale includes 5 different scenarios and questions related with these in which the participants give yes/no responses. The internal reliability was found to be between 0.72 and 0.84 for the pre-test, post-test and follow-up studies.

\section{Results}

First of all, the preliminary analyses showed that there was no significant difference between the intervention and control groups, for the study variables. Then, the means, standard deviations and bivariate correlations among main study variables were calculated. The results showed that there was a negative association between the cumulative family risk and moral development of the students at all three time points. The means of the moral development indicated that, control group students displayed a decline in the level of moral development, whereas there was no such a decline for the intervention group students, in between the pre-test and follow-up study.

We estimated models that included autoregressive effects using the MPLUS software. Each model included first and second order autoregressive paths and gender, family socio-economic status and cumulative family risk as the control variables. A multi-group analysis was used to test the intervention and control groups simultaneously. The model had satisfactory fit indices, $\chi^{2}(12)=49.597, \mathrm{p}=0.00$; CFI $=0.85$; RMSEA $=0.08$ and SRMR $=0.06$. Although the control group students showed higher levels of moral development than the intervention group, at the end of the follow-up study, the intervention group students were better in internalized moral development. While the control group students showed a decline, the intervention group students had constant levels with a slightly increasing level of moral development.

In addition to the comparison of control and intervention groups, the students were also compared according to their gender. This model also had satisfactory fit indices, $\chi^{2}(18)=24.943, p=0.12$; CFI $=0.95$; RMSEA $=0.05$ and SRMR $=0.05$. The girls showed higher levels of moral development in both control and intervention groups, than the boys. However, while both the girls and boys in the control group showed a decline, there was no decline in the level of moral development for the intervention group. In addition, the results of the intervention program indicated that, boys benefited from the program more than the girls (the effect size was $2 \%$ for the girls and $4 \%$ for the boys).

\section{Discussion and Conclusion}

This study aimed to better understand the dynamics of the early adolescence period and to examine the effects of an implemented intervention program to support the positive development of adolescents in moral developmental area. Early adolescence period was targeted because some general decline in well-being and development of adolescents occur during this period. The results of the study indicated that, PERGEL intervention was found to be 
effective in halting normative declines in the internalized moral development. Moreover, this study also showed that school-based interventions were effective and efficient in implementation. This study also aimed to enable the use of the training program at the guidance-counselling class periods at primary schools for all early adolescents. Cooperation is expected to be established with the Ministry of National Education. With this study, we aim to develop a unique, culture sensitive, and scientific grounded program benefitting from the best practices in the world. 


\section{Kaynakça / References}

Barrera, M., Biglan, A., Taylor, T. K., Gunn, B., Smolkowski, K., Black, C., Ary, V. D., \& Fowler, R.C. (2002). Early elementary school intervention to reduce conduct problems: A randomized trial with Hispanic and non-Hispanic children. Prevention Science, 3, 83-94.

Bebeau, M. J. (2002).The defining issues test and the four component model: Contributions to professional education. Journal of Moral Education, 31(3), 271-295.

Blum, R. W., \& Libbey, H. P. (2004). Wingspread declaration on school connections. Journal of School Health, 74(7), $233-234$.

Bornstein, M. H., \& Cote, L. R. (2006). Acculturation and parent-child relationships: Measurement and development. Mahwah, NJ: Lawrence Erlbaum.

Buchanan-Barrow, E., \& Barrett, M. (1998). Children's rule discrimination within the context of the school. British Journal of Developmental Psychology, 16(4), 539-551.

Campbell, F. A., \& Ramey, C. T. (1995). Cognitive and school outcomes for high-risk African-American students at middle adolescence: Positive effects of early intervention. American educational research journal, 32(4), 743-772.

Cardemil, E. V., Reivich, K. J., \& Seligman, M. E. (2002). The prevention of depressive symptoms in low-income minority middle school students. Prevention \& Treatment, 5, Article ID: 8.

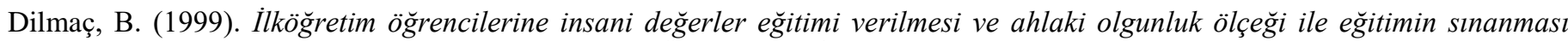
(Yayımlanmamış yükssek lisans tezi). Marmara Üniversitesi, İstanbul.

Durlak, J. A., Weissberg, R.P., Dymnicki, A. B., Taylor, R. D., \& Schellinger, K. B. (2011). The impact of enhancing students' social and emotional learning: A meta-analysis of school-based universal interventions. Child Development, 82(1), 405432 .

Eisenberg, N., \& Valiente, C. (2002). Parenting and children's prosocial and moral development. Handbook of Parenting, 5, 111142.

Elias, M. J. (Ed.). (1997). Promoting social and emotional learning: Guidelines for educators. Alexandria, VA: ASCD.

Erikson, E. H. (1959). Identity and the life cycle: Selected papers. Psychological issues, 1, 1-171.

Gardner, M., \& Steinberg, L. (2005). Peer influence on risk taking, risk preference, and risky decision making in adolescence and adulthood: an experimental study. Developmental Psychology, 41(4), 625-635.

Gibbs, J. C., Basinger, K. S., Grime, R. L., \& Snarey, J. R. (2007). Moral judgment development across cultures: Revisiting Kohlberg's universality claims. Developmental Review, 27, 443-500.

Gillham, J. E., Reivich, K. J., Jaycox, L. H., \& Seligman, M. E. (1995). Prevention of depressive symptoms in schoolchildren: Two-year follow-up. Psychological Science, 6(6), 343-351.

Gillham, J. E., Reivich, K. J., Freres, D. R., Lascher, M., Litzinger, S., Shatté, A., \& Seligman, M. E. (2006). School-based prevention of depression and anxiety symptoms in early adolescence: A pilot of a parent intervention component. School Psychology Quarterly, 21(3), 323-348.

Gottfredson, D. C., Gerstenblith, S. A., Soulé, D. A., Womer, S. C., \& Lu, S. (2004). Do after school programs reduce delinquency? Prevention Science, 5(4), 253-266.

Gölcük, S. (2010). İlkögrretim II. kademe öğrencilerinde din kültürü ve ahlâk bilgisi düzeyi ile ahlâk gelişimi arasındaki ilişkiler (Yayınlanmamış doktora tezi). Dokuz Eylül Üniversitesi, İzmir.

Haan, N., Langer, J., \& Kohlberg, L. (1976). Family patterns of moral reasoning. Child Development, 47, $1204-1206$.

Holsen, I., Smith, B. H., \& Frey, K. S. (2008). Outcomes of the social competence program Second Step in Norwegian elementary schools. School Psychology International, 29(1), 71-88.

Kağıtçıbaşı, Ç. (1990). Family and socialization in cross-cultural perspective: A model of change. In J. Berman (Ed.), Crosscultural perspectives: Nebraska symposium on motivation (pp. 135-200). Lincoln, NE: Nebraska University Press. 
Kağıtçıbaşı, Ç. (2002). Psychology and human competence development. Applied Psychology, 51(1), 5-22.

Kağıtçıbaşı, Ç. (2012). Benlik, aile ve insan gelişimi: Kültürel psikoloji (3. baskı). İstanbul: Koç Üniversitesi Yayınları.

Kağıtçıbaşı, Ç., \& Cemalcılar, Z. (2014). Dünden bugüne insan ve insanlar: Sosyal psikolojiye girişs (16. Bask1). İstanbul: Evrim Yayınevi.

Kağıtçıbaşı, Ç., Sunar, D., \& Bekman, S. (2001). Long-term effects of early intervention: Turkish low-income mothers and children. Journal of Applied Developmental Psychology, 22(4), 333-361.

Kağıtçıbaşı, Ç., Sunar, D., Bekman, S., Baydar, N., \& Cemalcılar, Z. (2009). Continuing effects of early enrichment in adult life: The Turkish Early Enrichment Project 22 years later. Journal of Applied Developmental Psychology, 30(6), $764-779$.

Kohlberg, L. (1971). Stages of moral development as a basis for moral education. In C. M. Beck, B. S. Crittenden, \& E. V. Sullivan (Eds.), Moral education: Interdisciplinary approaches (pp. 23-92) Toronto: Toronto University Press.

Lerner, R. M., Fisher, C. B., \& Weinberg, R. A. (2000). Toward a science for and of the people: Promoting civil society through the application of developmental science. Child Development, 71, 11-20.

Lerner, R. M., Lerner, J. V., Almerigi, J. B., Theokas, C., Phelps, E., Gestsdottir, S., Naudeau, S., ... \& von Eye, A. (2005). Positive youth development, participation in community youth development programs, and community contributions of fifth-grade adolescents: Findings from the first wave of the 4-H study of positive youth development. The Journal of Early Adolescence, 25(1), 17-71.

Mays, D. B. (2009). A quantitative study of adolescent moral decision making (Unpublished doctoral dissertation). Capella University, Minneapolis, MN.

Narvaez, D. (2006). Guide for using the Positivity Scale. Notre Dame, IN: Center for Ethical Education, University of Notre Dame.

Nipkow, K. E., \& Schweitzer, F. (1985). Moral education in West Germany. Journal of Moral Education, 14(3), $194-203$.

Payton, J. W., Wardlaw, D. M., Graczyk, P. A., Bloodworth, M. R., Tompsett, C. J., \& Weissberg, R. P. (2000). Social and emotional learning: A framework for promoting mental health and reducing risk behavior in children and youth. Journal of School Health, 70(5), 179-185.

Pellegrini, A. D., Bartini, M., \& Brooks, F. (1999). School bullies, victims, and aggressive victims: Factors relating to group affiliation and victimization in early adolescence. Journal of educational psychology, 91(2), 216-224.

Piaget, J. (1932). The moral development of the child. London: Kegan Paul.

Quayle, D., Dziurawiec, S., Roberts, C., Kane, R., \& Ebsworthy, G. (2001). The effect of an optimism and lifeskills program on depressive symptoms in preadolescence. Behaviour Change, 18(4), 194-203.

Ragozzino, K., Resnik, H., Utne-O’Brien, M., \& Weissberg, R. P. (2003). Promoting academic achievement through social and emotional learning. Educational Horizons, 81(4), 169-171.

Reid, M. J., Webster-Stratton, C., \& Baydar, N. (2004). Halting the development of conduct problems in head start children: The effects of parent training. Journal of Clinical Child and Adolescent Psychology, 33(2), 279-291.

Roberts, C. (2006). Embedding mental health promotion programs in school contexts: The Aussie Optimism Program. ISSBD Newsletter, 50, 1-4.

Roth, J., \& Brooks-Gunn,J. (2003). Youth development programs. Journal of Adolescent Health, 32, 170-182.

Schlaefli, A., Rest, J. R., \& Thoma, S. J. (1985). Does moral education improve moral judgment? A meta-analysis of intervention studies using the Defining Issues Test. Review of Educational Research, 55(3), 319-352.

Schmid, K. L., Phelps, E., \& Lerner, R. M. (2011). Constructing positive futures: Modeling the relationship between adolescents' hopeful future expectations and intentional self-regulation in predicting positive youth development. Journal of Adolescence, 34(6), 1127-1135.

Seçer, Z. (2003). Yoğun Düşünme Eğitimi Programının çocukların ahlaki yargılarına etkisinin incelenmesi (Yayınlanmamış doktora tezi). Selçuk Üniversitesi, Konya. 
Seçer, Z., Çağdaş, A., \& Seçer, F. (2006). Çocukların okul ortamındaki ahlaki ve sosyal kuralları ayırt etme becerisinin çeşitli değişkenler açısından incelenmesi. Pamukkale Üniversitesi Ĕgitim Fakültesi Dergisi, 20, 69-81.

Seligman, M., Reivich, K., Jaycox, L., \& Gilham, J. (1995). The optimistic child. Sydney: Random House.

Senemoğlu, N. (1997). Gelişim, ögrenme ve ögretim: Kuramdan uygulamaya, Ankara: Pegem.

Silberman, M. A., \& Snarey, J. (1993). Gender differences in moral development during early adolescence: The contribution of sex-related variations in maturation. Current Psychology, 12(2), 163-171.

Stephens, D. G. (2009). A correlation study on parental attachment and moral judgment competence of millennial generation college students (Unpublished doctoral dissertation). The University of Nebraska, Lincoln, NB.

Sümer, N., \& Güngör, D. (1999). Yetişkin bağlanma stilleri ölçeklerinin Türk örneklemi üzerinde psikometrik değerlendirmesi ve kültürlerarası bir karşılaştırma. Türk Psikoloji Dergisi, 14(43), 71-106.

Tolunay, A. (2001). The relationship between religiosity, dogmatism and moral reasoning (Unpublished master thesis). Boğaziçi University, İstanbul.

Walker, L. J., \& Taylor, J. H. (1991). Family interactions and the development of moral reasoning. Child Development, 62(2), 264-283.

White Jr, R. D. (1999). Are women more ethical? Recent findings on the effects of gender upon moral development. Journal of Public Administration Research and Theory, 9(3), 459-472.

Yu, D. L., \& Seligman, M. E. P. (2002). Preventing depressive symptoms in Chinese children. Prevention \& Treatment, 5, Article ID: 9. 